\title{
Effects of slope aspect on altitudinal pattern of soil $C: N: P$ stoichiometry in alpine forest of Tibet
}

\author{
Jiangrong $\mathrm{Li}^{1,2}$, Qiqiang Guo ${ }^{1,3}$, Heping $\mathrm{Ma}^{1,2}$, and Weilie Zheng ${ }^{1,2, *}$ \\ ${ }^{1}$ Institute of Tibet Plateau Ecology, Tibet Agricultural and Animal Husbandry University, Nyingchi, 860000, China \\ ${ }^{2}$ Key Laboratory of Forest Ecology in Tibetan Plateau (Tibet Agricultural \& Animal Husbandry University), Ministry of Education, \\ Nyingchi, 860000, China \\ ${ }^{3}$ Institute for Forest Resources \& Environment of Guizhou, Guizhou University, Guiyang, 550025, China
}

\begin{abstract}
Knowledge of altitudinal patterns in soil C, N and P distribution is important for understanding biogeochemical processes in mountainous forests, yet the influence of slope aspects on soil stoichiometry has been largely neglected in previous studies. In this paper, a total number of 150 topsoil samples at four altitudes $(3700,3900,4100,4380 \mathrm{~m}$ a.s.1.) on sunny and shady slopes of Sygera mountains in the Southeastern Tibet were collected. Soil $\mathrm{C}, \mathrm{N}$ and $\mathrm{P}$ contents, and $\mathrm{pH}$, were measured. Soil temperature, moisture and richness of plant species were investigated at each sampling site. The results showed that: 1) in sunny slope, soil $\mathrm{C}, \mathrm{N}$ and $\mathrm{P}$ concentrations increased with the increase in altitude, whereas soil C:N, $\mathrm{C}: \mathrm{P}$, and $\mathrm{N}: \mathrm{P}$ decreased along the altitudinal gradient on $\mathrm{s}$. Soil moisture was the main regulator of soil nutrition and stoichiometric ratios. 2) In shady slope, soil $\mathrm{C}$ and $\mathrm{N}$ contents had no significant difference along the altitudinal gradient except the higher values at low altitude, whereas soil $\mathrm{P}$ increased first and then decreased. Soil C:N increased with the increase in altitude, whereas C:P and N:P decreased first and then increased. Soil temperature and species richness were the main factors influencing soil nutrition and stoichiometric ratios. 3) Decoupling of soil C:N:P stoichiometry was observed in shady slope owing to changes in soil $\mathrm{pH}$ and temperature. 4) The rich contents of soil $\mathrm{C}$ and $\mathrm{P}$ were observed at two slopes along the altitudinal gradient, and high capacity of $\mathrm{N}$ supply existed at the topsoil in shady slope. These results suggested that slope aspect plays an important role in shaping the altitudinal pattern of soil C:N:P stoichiometry in mountainous forests.
\end{abstract}

\section{Introduction}

Stoichiometry of soil carbon $(\mathrm{C})$, nitrogen $(\mathrm{N})$ and phosphorus (P) is important foundation for understanding biogeochemical processes in terrestrial ecosystems. Increased research attention has been paid to spatial patterns of $\mathrm{C}, \mathrm{N}$ and $\mathrm{P}$ distribution in mountainous forests, and immense variability of their altitudinal distribution has been recognized in various regions [1-2]. There are reports that soil $\mathrm{C}$ and $\mathrm{N}$ concentrations were higher at medium altitudes than that at low or high altitudes, and $\mathrm{P}$ concentrations increased significantly with the rising of altitude, suggesting an increase in $\mathrm{N}$ limitation to forests at higher elevations [34]. Other studies observed that soil $\mathrm{C}$ and $\mathrm{N}$ concentrations were relatively stable along the altitudinal gradients, but soil P concentration kept a decreasing trend with the increase in elevation, suggesting an increase in $\mathrm{P}$ limitation to forests at higher elevations [5]. With regard to the ratios of these elements, previous studies showed that, with increase in altitude, soil C:N and $\mathrm{C}: \mathrm{P}$ initially decrease and then increase, whereas $\mathrm{N}: \mathrm{P}$ is opposite [6], whereas others showed a consistent increase in soil $C: N, C: P$ and $N: P$ with increase in altitude [7]. To date, the altitudinal pattern of $\mathrm{C}, \mathrm{N}, \mathrm{P}$ and their ratios is still inconclusive.
An important characteristic of mountainous environment is the slope aspects. However, the slope aspects have been largely neglected in altitudinal gradient studies of soil stoichiometry. Here we hypothesize that slope aspects play a role in generating difference in soil $\mathrm{C}, \mathrm{N}$, and $\mathrm{P}$ stoichiometry along altitudinal gradient, because the sunshine and precipitation processes differ with slope aspects resulting in difference in soil temperature, moisture, and above ground vegetation which all affect the soil contents of C, $\mathrm{N}$ and $\mathrm{P}$.

The Sygera mountains distribute typical primordial dark coniferous forests growing at elevations ranging from 3700 to $4380 \mathrm{~m}$ above sea level in both sunny and shady slopes, making it an ideal area for comparing altitudinal patterns of soil stoichiometry at different slopes. Previous studies in Sygera mountains demonstrated that tree growth, plant communities, and soil bacterial communities change remarkably with the altitude [8-11]. However, current knowledge of the role of slope aspects on these changes as well as soil stoichiometry is limited. The objectives of this study were (1) to characterize soil $\mathrm{C}, \mathrm{N}$, and P contents and stoichiometry along altitudinal gradient on sunny and shady slopes in Sygera mountains, and (2) to identify the

\footnotetext{
${ }^{*}$ Corresponding author: zhengweilie@xza.edu.cn
} 
dominant factors regulating spatial difference in soil C, $\mathrm{N}, \mathrm{P}$ contents and their stoichiometry.

\section{Materials and Methods}

\subsection{Site description}

The research was conducted on the east side of Sygera mountains, as high as 5,200 m a.s.l., in Nyingchi County, Southeastern Tibet, China. Dominant tree species in the mountainous forests are Sabina saltuaria Rehder in sunny slope and Abies georgei var. smithii in shady slope. According to meteorological records from 1985 to 2019 at the Linzhi Forest Ecosystem Observation Station $\left(29^{\circ} 39^{\prime} 1^{\prime \prime} \mathrm{N}, 94^{\circ} 42^{\prime} 53^{\prime \prime} \mathrm{E}, 3900 \mathrm{~m}\right.$ a.s.l.), mean annual temperature is $-0.75^{\circ} \mathrm{C}$ with the maximum and minimum monthly mean temperatures being $8.36^{\circ} \mathrm{C}$ (July) and $-3.92^{\circ} \mathrm{C}$ (January), respectively. Total annual precipitation is $1245 \mathrm{~mm}$, and approximately $80 \%$ precipitation falls during June to September. The annual mean sunshine is 1236 hours, and the evaporation capacity is $596 \mathrm{~mm}$. The soil was brown forest soil with $\mathrm{pH}$ values of 4.0-6.0 [12].

\subsection{Soil sample collection and element determination}

Plots of size $10 \mathrm{~m} \times 10 \mathrm{~m}$ were established at four altitudes, 3700 (Plot numbers: 1-5), 3900 (Plot numbers: 6-10), 4100 (Plot numbers: 11-15) and 4380 (Plot numbers: 16-20) $\mathrm{m}$ a.s.l. in sunny (southeast) slope (Plot code: o ) and shady (north) slope (Plot code: - ), respectively, in the study area (Fig. 1). The uppermost plots were in the treeline ecotones. Five plots, greater than $100 \mathrm{~m}$ apart from each other, were established at each altitude in each slope aspects, resulting in a total number of 40 plots under study. Along a diagonal line of each plots, three soil samples in layer $0-10 \mathrm{~cm}$ (with the litterfalls in the surface removed) were collected with a $100 \mathrm{~cm} 3$ ring knife. A total number of 120 soil samples was collected from August 5 to 25 in 2018.

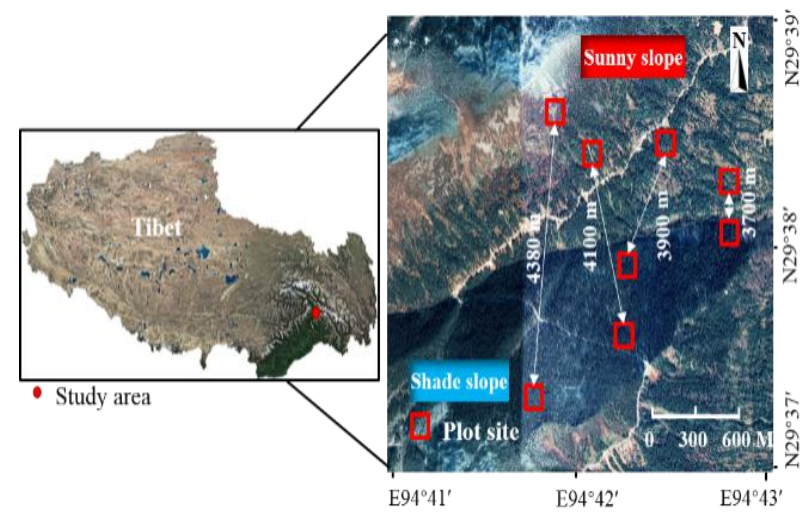

Fig. 1. Location of study area and plot sites on east side of Sygera mountains, Southeastern Tibet. Red boxes and the associated numbers indicate plot sites and their elevations.
During the sampling, soil temperature, moisture and $\mathrm{pH}$ of each soil sample were measured in situ using WET-2 (Delta-T, UK) and IQ160 (Spectrum, USA). All the samples were naturally air-dried, grounded, and screened at $0.1 \mathrm{~mm}$ sieve to determine the nutrient contents. Carbon content of samples were measured through external heating of soil potassium dichromate [13], and total $\mathrm{N}$ and total $\mathrm{P}$ contents of samples were determined through Kjeldahl's method and molybdenum-antimony anticolorimetry, respectively [14].

\subsection{Plant species survey and diversity index calculation}

In each plot, the plant species were identified and their height and coverage were measured. In addition, the diameter at breast height (DBH, $1.3 \mathrm{~m}$ ) of all individual trees, basal diameter of shrub species and number of clustered herbs were recorded in each plot. Species richness (S) was calculated for each altitudinal zone [15].

\subsection{Data analysis}

Soil $\mathrm{C}, \mathrm{N}$ and $\mathrm{P}$ contents and their stoichiometric ratios were compared among different altitudes and between the sunny and shady slopes. The significance $(p<0.05)$ of their difference was determined using Fisher's LSD test. Pearson correlation was used to determine the relationship between different nutrient contents in the two slope aspects. Redundancy analysis (RDA) was a direct gradient analysis technique, which is the fitting value matrix of multiple linear regression between response variable matrix and explanatory variable for principal component analysis [16]. It was performed to determine the environmental factors influencing the soil stoichiometric characteristics. RDA was conducted using CANOCO 5.0 for Windows [17].

\section{Results}

\subsection{Soil environment along altitudinal gradients of sunny and shady slopes}

Soil temperature decreased with the increasing altitude, and their values were significantly higher in sunny slope than in shady slope at the same altitude (Fig. 2a). The pattern of soil moisture was opposite to that of soil temperature (Fig. 2b). The values of soil $\mathrm{pH}$ were generally higher in sunny slope than in shady slope and similar in two slopes at treeline ecotones (Fig. 2c). The highest $\mathrm{pH}$ occurred at $4100 \mathrm{~m}$ a.s.l. on sunny slope and at $3900 \mathrm{~m}$ a.s.l. on shady slope. Species richness decreased with the increase in altitude at both slopes and it was consistently higher in shady slope than sunny slope (Fig. 2d). 

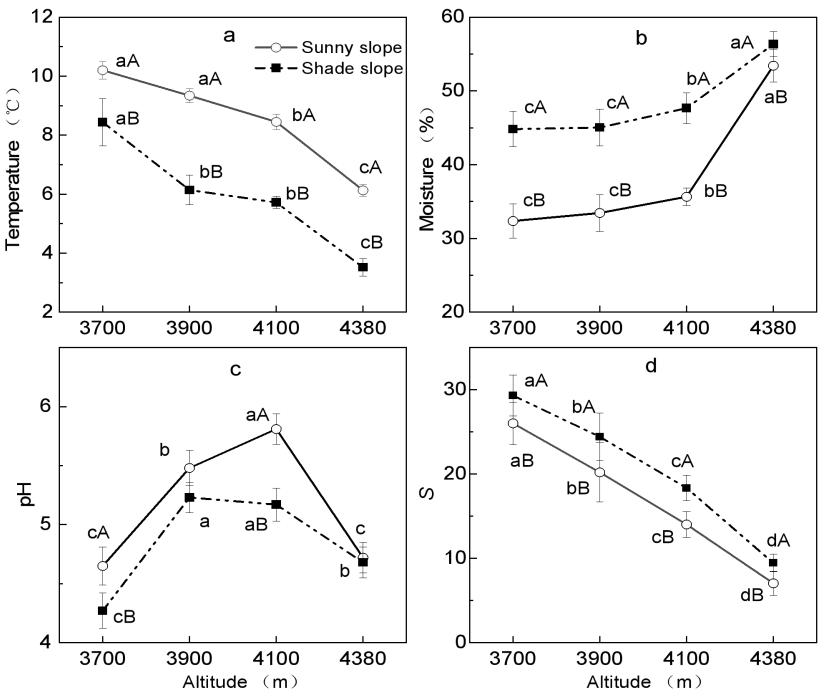

Fig. 2. Soil environments at four altitudes (3700, 3900, 4100, $4380 \mathrm{~m}$ a.s.l.) of two slope aspects (sunny, shade) at the east side of Sygera mountains. Temperature, moisture, $\mathrm{pH}$, and species richness are expressed as Mean $\pm \operatorname{SE}(n=15)$. The capital letters indicate significant differences between two slope aspects, and the lowercase ones indicate significant differences among different altitudes in the same slope aspect, respectively $(\mathrm{P}<0.05)$.

\subsection{Soil stoichiometry along altitudinal gradients of sunny and shady slopes}

The concentrations of soil $\mathrm{C}, \mathrm{N}$ and $\mathrm{P}$ increased with the increase in altitude on sunny slope but their pattern in shady slope was different (Fig. 3a-c). In the shady slope, the soil carbon content was higher than that in sunny slope, and the maximum value appeared at $3700 \mathrm{~m}$ a.s.l.; soil $\mathrm{N}$ content dropped from $3700 \mathrm{~m}$ a.s.1. to $4100 \mathrm{~m}$ a.s.1. and remained similar level to the treeline ecotone; soil $\mathrm{P}$ content increased with the increasing altitude till $4100 \mathrm{~m}$ a.s.l. and dropped remarkably to treeline ecotone.
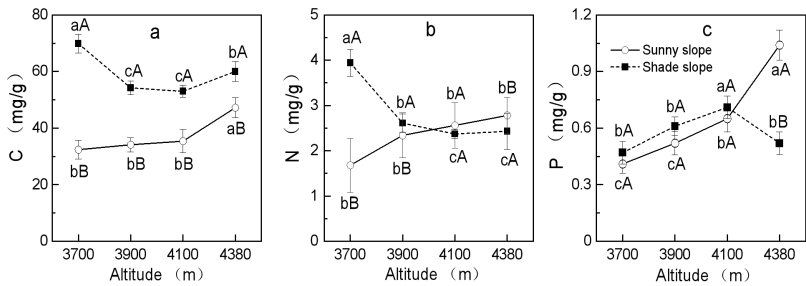

Fig. 3. Soil carbon, nitrogen and phosphorus contents in $0-10$ $\mathrm{cm}$ at four altitudes $(3700,3900,4100,4380 \mathrm{~m}$ a.s.1.) in the sunny and shady slopes of Sygera mountains. Values are expressed as Mean \pm SE $(n=15)$. The capital letters indicate significant difference between the two slopes, and the lowercase ones indicate significant difference among different altitudes in the same slope $(\mathrm{P}<0.05)$.

There were significant correlations among soil $\mathrm{C}, \mathrm{N}$ and $\mathrm{P}$ in sunny slope $(P<0.05)$, whereas in shady slope, significant correlations only existed between $\mathrm{C}$ and $\mathrm{N}$ (Fig. 4). Further examination of the stoichiometric ratios of soil $\mathrm{C}, \mathrm{N}$, and $\mathrm{P}$ showed that there was a very significant correlation between $\mathrm{C}$ and $\mathrm{N}$ in both sunny and shady slopes, as well as a significant correlation between $\mathrm{C}$ and $\mathrm{P}, \mathrm{N}$ and $\mathrm{P}$ in sunny slope (Fig. 4).
Stoichiometric ratios of soil $\mathrm{C}, \mathrm{N}$, and $\mathrm{P}$ varied with the altitudes and slopes (Fig. 5). In sunny slope, C:N values decreased first and then increased with the increasing altitude, whereas $\mathrm{N}: \mathrm{P}$ values showed a decreasing trend. In shady slope, there was a significant increase of $\mathrm{C}: \mathrm{N}$ with the increasing altitude, whereas $\mathrm{N}: \mathrm{P}$ and $\mathrm{C}: \mathrm{P}$ kept the same pattern of change, that is, first decreasing and then increasing. Comparison of the stoichiometric ratios at the same altitude between the two slopes showed that $\mathrm{C}: \mathrm{N}, \mathrm{N}: \mathrm{P}$ and $\mathrm{C}: \mathrm{P}$ all exhibited significant or extremely significant differences except $\mathrm{N}: \mathrm{P}$ at 3900 and $4100 \mathrm{~m}$ a.s.l.
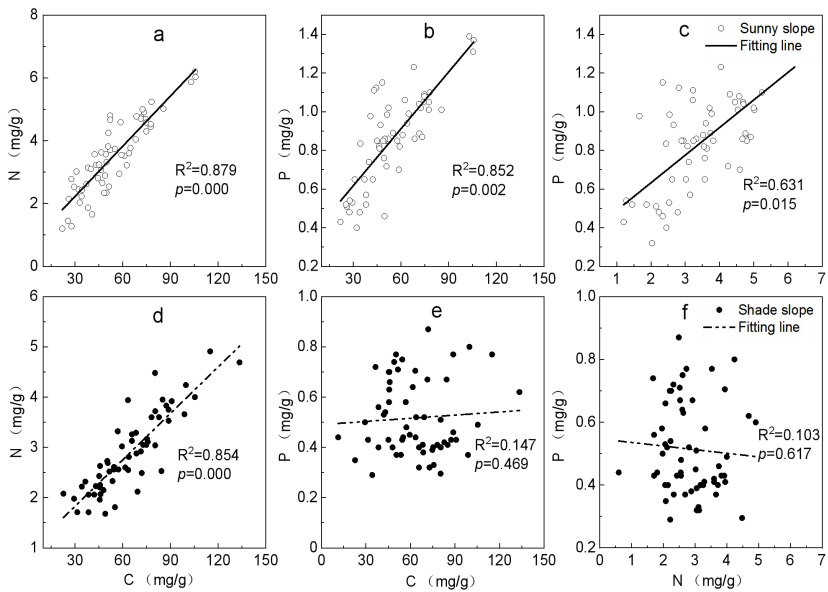

Fig. 4. Relationships among soil $\mathrm{C}, \mathrm{N}$, and $\mathrm{P}$ contents in sunny and shady slopes in the east side of Sygera mountains. The points represent measured values for each soil sample $(n=60)$.
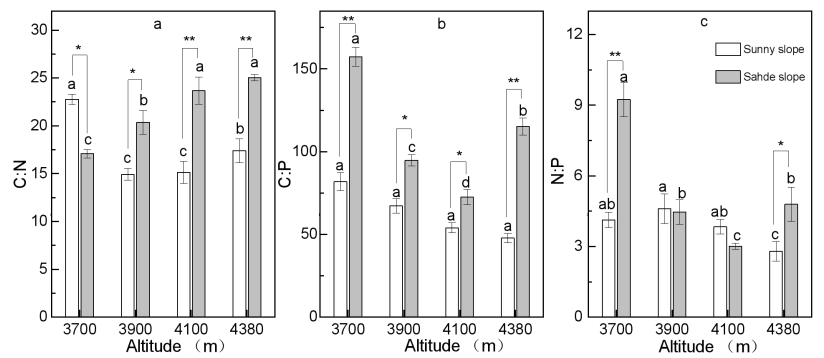

Fig. 5. Comparison of soil $C: N, C: P$, and $N: P$ values at four altitudes $(3700,3900,4100,4380 \mathrm{~m}$ a.s.l.) of the two slopes in the east side of Sygera mountains. Values are expressed as Mean \pm SE $(n=15)$. Different letters above the bar indicate significant difference $(\mathrm{P}<0.05)$ among different altitudes in the same slope. Difference of the same altitude between the two slopes is represented by $*(\mathrm{P}<0.05)$ and $* *(\mathrm{P}<0.01)$, respectively.

\subsection{Factors influencing the stoichiometric characteristics of soil $\mathbf{C}, \mathrm{N}$, and $\mathrm{P}$}

The results of the RDA analysis showed that the first two sorting axes represented $96.27 \%$ and $98.85 \%$ of the variance in stoichiometry of soil $\mathrm{C}, \mathrm{N}$, and $\mathrm{P}$ contents in sunny and shady slopes, respectively (Fig. 6a, 6b). In sunny slope, soil $\mathrm{C}, \mathrm{N}$, and $\mathrm{P}$ contents were positively related to soil moisture in higher altitude, and their stoichiometric ratios were positively related to soil temperature and species richness in lower altitude. In shady slope, soil C:P and N:P were positively related to 
soil temperature and species richness in lower altitude, and soil $\mathrm{C}: \mathrm{N}$ was positively related to soil moisture in higher altitude. Partly, soil $\mathrm{pH}$ affected the soil $\mathrm{P}$ content in shady slope.

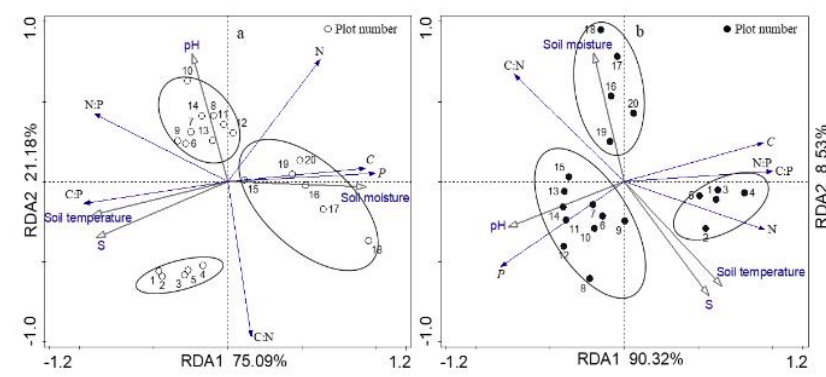

Fig. 6. $2 \mathrm{D}$ sequence diagram of RDA analysis between soil environmental and vegetation factors and $\mathrm{C}, \mathrm{N}, \mathrm{P}$, and their stoichiometric ratios at sunny slope (a) and shady slope (b) in Sygera Mountains. The circles "o " and dots ". " represent plots in sunny and shady slopes, respectively. The numbers indicate plot No. The plots $1-5$ are located at $3700 \mathrm{~m}$ a.s.1.; Plots 6-10 are located at $3900 \mathrm{~m}$ a.s.l.; Plots 11-15 are located at $4100 \mathrm{~m}$ a.s.l.; and Plots $16-20$ are located at $4380 \mathrm{~m}$ a.s.1..

\section{Results and Discussion}

\subsection{Altitudinal patterns in soil $C, N$, and $P$ contents at sunny and shady slope aspects}

Our results showed that the soil $\mathrm{C}, \mathrm{N}$, and $\mathrm{P}$ contents increases with the increase in altitude in sunny slope, whereas they exhibit a non-uniform pattern in shady slope. This observation suggested that environmental factors associated with altitudinal change affect the spatial distribution of soil nutrition contents differently in the two slopes.

Factors causing the altitudinal pattern of soil nutrients in sunny slope was soil moisture condition, as demonstrated by the results of RDA analysis (Fig. 6a). In sunny slope, soil moisture was relatively lower and no significant fluctuation from 3700 to $4100 \mathrm{~m}$ a.s.l. (Fig. $2 \mathrm{~b}$ ), providing common habitats for soil $\mathrm{C}, \mathrm{N}$, and $\mathrm{P}$ mineralization. Although the higher water content was observed at $4380 \mathrm{~m}$ a.s.l., this did not significantly alter altitudinal pattern of soil nutrients.

Non-uniform altitudinal pattern of soil nutrients in shady slope was likely caused by multiple factors. According to the RDA analysis, soil temperature, species richness, and soil $\mathrm{pH}$ all affected soil nutrient contents (Fig. 6b). Previous research showed that soil $\mathrm{C}$ and $\mathrm{N}$ is mainly derived from litter returning to the soil after plant death [18-20]. The lower soil temperature along the altitudinal gradient reduced the rate of the litter decomposition, inhibiting the $\mathrm{C}$ and $\mathrm{N}$ inputs. However, the higher $\mathrm{C}$ and $\mathrm{N}$ contents in soil might be a result of rich plant species [21-22]. The fluctuation of soil $\mathrm{pH}$ led to non-uniform pattern of soil $\mathrm{P}$ content. Non-significant correlations between $\mathrm{C}$ and $\mathrm{P}, \mathrm{N}$ and $\mathrm{P}$ also indicated the non-uniform pattern of soil nutrients in shady slope (Fig. 4e-f).

Soil nutrient content in shady slope was higher than that in sunny slope except $P$ at $4380 \mathrm{~m}$ a.s.l. in sunny slope (Fig. 3 a-c). These were mainly associated with the situation of species composition. The decreasing species quantity in sunny slope lead to less litter (Fig. 2 d), and limit the supply of $\mathrm{C}$ and $\mathrm{N}$ along altitudinal gradient. However, the increase of soil $\mathrm{pH}$ was helpful to improve microbial activity [23] and soil $\mathrm{C}, \mathrm{N}$ accumulation. In detail, soil acidity usually inhibits microbial activity and bacterial growth [24], mainly owing to the higher $\mathrm{H}+$ concentration disrupting the permeability and stability of bacterial cell membranes [25]. $\mathrm{P}$ content is mainly related to habitat conditions and soil lithology [26]. During the field sampling, we found no significant difference in soil texture between the two slopes. Thus, habitat differences should be the main reason for the difference of soil $\mathrm{P}$ content in $4380 \mathrm{~m}$ a.s.l. between the two slope aspects. In sunny slope, the long sunshine hours and soil moisture promoted soil $\mathrm{P}$ mineralization and led to the rich $\mathrm{P}$ content.

In sunny slope, the positive association between soil $\mathrm{C}, \mathrm{N}, \mathrm{P}$ contents, ratio of $\mathrm{C}: \mathrm{P}$ and soil temperature and species richness implied that high temperature was beneficial to microbial activity [27-28] and litter decomposition rate [29-30], accelerating soil nutrient enrichment. Simultaneously, the rich species composition promoted the number of plant remains, which was the main source of soil $\mathrm{C}$ in forest ecosystem [18,31]. Therefore, soil C:P ratio was also rich.

\subsection{Decoupling of soil $C: N: P$ stoichiometry in shady slope}

The ratios of soil $\mathrm{C}, \mathrm{N}$ and $\mathrm{P}$ contents were consistent along altitudinal gradient in sunny slope, whereas, the ratios of C:P and N:P decoupled in shady slope (Fig. 4), suggesting that the mechanisms regulating soil $\mathrm{C}: \mathrm{N}: \mathrm{P}$ stoichiometry in sunny slope is different from that of shady slope. We propose that the combination of soil $\mathrm{pH}$ and temperature caused the decoupling of soil stoichiometry.

According to RDA analysis, soil $\mathrm{pH}$ and temperature had significant correlation with $\mathrm{P}$ content, $\mathrm{C}: \mathrm{P}$ and $\mathrm{N}: \mathrm{P}$ ratios. The reduction of soil $\mathrm{P}$ content appeared at high altitudes (4380 $\mathrm{m}$ a.s.1.) in shady slope, where is characterized by acidification and moist conditions in soil. These habitats could reduce soil aeration and microbial activity, which is not beneficial to the mineralization of $\mathrm{P}$ in the soil [32-33]. Meanwhile, soil temperature had positive correlation with $\mathrm{C}: \mathrm{P}$ and $\mathrm{N}: \mathrm{P}$ (Fig. 6b). In shady slope at high altitudes, lower temperature also has a similar effect leading to high acidity in soil. Not only the rate of soil mineralization slowed down, but also the decay of animal and plant residues [5,34-35]. Both processes reduce the input of organic and inorganic phosphorus as well as soil $\mathrm{C}$ and $\mathrm{N}$ into soil. As a whole, the change of soil $\mathrm{P}$ content resulted the change in pattern of soil $\mathrm{C}: \mathrm{N}: \mathrm{P}$ stoichiometry.

\subsection{Decoupling of soil C:N:P stoichiometry in shady slope}

The rich contents of soil $\mathrm{C}$ and $\mathrm{P}$ were one of the soil characteristics in Sygera Mountain. According to soil 
stoichiometry, the ranges of soil $\mathrm{C}: \mathrm{N}$ was $14.92-22.77$ and 17.08-25.02 at sunny and shady slopes, respectively. Previous researcher reported that soil C:N in Chinese frigid highland was 11.7 [36-37], which was lower than the values in our study. In addition, the values of C:P ratio (49.69-82.18 at sunny slope; 71.73-156.87 at shady slope) were greater than those in Chinese frigid highland (24.0) [37-39]. These observations indicated that soil carbon content was rich in our study area.

The soil had richer $\mathrm{N}$ supply capacity at shady slope than that in sunny slope. Soil N:P ratio was an important indicator of $\mathrm{N}$ nutrient availability, and it was usually influenced by environmental factors and soil properties in forest ecosystems [26,40-42]. In our research, soil N:P ratios ranged from 2.79 to 4.61 in sunny slope and from 3.01 to 9.24 in shady slope, respectively. According to the LFEOS records, there was more gustiness rainfall at shady slopes, which caused atmosphere $\mathrm{N}$ subsidence [43]. Meanwhile, $\mathrm{N}$ in topsoil layer would migrate to lower elevations with rain. Therefore, the maximum of $\mathrm{N}: \mathrm{P}$ were observed in shady slope at the lowest altitude (3700 $\mathrm{m}$ a.s.1.).

\section{Conclusion}

In summary, slope aspect significantly affected soil $\mathrm{C}, \mathrm{N}$, and $\mathrm{P}$ contents and stoichiometric ratios along the altitudinal gradients in primordial dark coniferous forests of Southeast Tibetan Plateau. Uniform altitudinal pattern of soil $\mathrm{C}, \mathrm{N}$, and $\mathrm{P}$ appeared in sunny slope, while decoupling of soil $\mathrm{C}: \mathrm{N}: \mathrm{P}$ stoichiometry in shady slope was observed. Comprehensive analysis showed that soil $\mathrm{C}, \mathrm{N}$, and $\mathrm{P}$ stoichiometric ratios were mainly affected by moisture in sunny slope, and by soil temperature and species richness in shady slope, respectively. These findings implied that slope aspect increases the complexity and heterogeneity of soil nutrients along altitudinal gradient in alpine region. Nevertheless, further studies on response of soil microbial activity to change of soil $\mathrm{pH}$ are required to clarify the characteristics of soil nutrient cycling under global change.

\section{Acknowledgments}

This work was supported by the Tibetan Linzhi National Forest Ecological Research Station (2018-LYPT-DW-090) and the National Science Foundation of China (31660215, 41061033). We are grateful to Dr. Qi-Bin Zhang (Institute of Botany, Chinese Academy of Sciences) for providing valuable comments and revising the manuscript.

\section{References}

[1] Lu, M., Cheng, S., Fang, H., et al., 2021. Organic nitrogen addition causes decoupling of microbial nitrogen cycles by stimulating gross nitrogen transformation in a temperate forest soil. Geoderma. 385(1-3): 114886. https://doi.org/10.1016/j.geoderma.2020.114886

[2] J, Alahuhta., Lindholm, M., Bove, C.P., et al. 2018. Global patterns in the metacommunity structuring of lake macrophytes: regional variations and driving factors. Oecologia. 188: 1167-1182. https://doi.org/10.1007/s00442-018-4294-0

[3] Cui, Y., Bing, H., Fang, L., et al., 2019. Extracellular enzyme stoichiometry reveals the carbon and phosphorus limitations of microbial metabolisms in the rhizosphere and bulk soils in alpine ecosystems. Plant Soil. https://doi:10.1007/s11104-019-04159-x

[4] Zhang, W., Liu, W., Xu, M., et al., 2019. Response of forest growth to $\mathrm{C}$ : N: P stoichiometry in plants and soils during robinia pseudoacacia afforestation on the Loess Plateau, China. Geoderma. 337: 280289.

https://doi.org/10.1016/j.geoderma.2018.09.042

[5] Chen, D.D., Li, Q., Liu, Z., et al., 2020. Variations of forage yield and nutrients with altitude gradients and their influencing factors in alpine meadow of Sanjiangyuan, China. Journal of Soil Science and Plant Nutrition. 20: 2164-2174. https://doi.org/10.1007/s42729-020-00284-0

[6] Li, D., Wang, Z., Tian, H., et al., 2017. Carbon, nitrogen and phosphorus contents in soils on taibai mountain and their ecological stoichiometry relative to elevation. Acta Pedofil Sinica. 54 (1): 160-170. (In Chinese) https://doi.org/10.11766/trxb201604140096

[7] Feng, J., Tang, M., Zhu, B., 2021. Soil priming effect and its responses to nutrient addition along a tropical forest elevation gradient. Global Change Biology. 27(12): 2793-2806 https://doi.org/10.1111/gcb.15587

[8] Jia, X., Chen, S., Yang, Y., et al., 2017. Organic carbon prediction in soil cores using VNIR and MIR techniques in an alpine landscape. Scientific Reports. $\quad 7(1): \quad 2144$. https://doi.org/10.1038/s41598-017-02061-z

[9] Zhong, H., Smith, C., Robinson, B., et al., 2020. Soil phosphorus dynamics along a short - term ecological restoration trajectory of a coastal sandplain forest in New Zealand. Land Degradation \& Development. 32: 1250-1261. https://doi.org/10.1002/ldr.3782

[10] Ma, H., Yang, X., Guo, Q., et al., 2016. Soil organic carbon pool along different altitudinal level in the Sygera Mountains, Tibetan Plateau. Journal of Mountain Science. 13(3): 476-483. https://doi.org/10.1007/s11629-014-3421-6

[11] Suonan, J., Classen, A.T., Sanders, N.J., et al., 2019. Plant phenological sensitivity to climate change on the tibetan plateau and relative to other areas of the world. Ecosphere. 10(1): e02543. https://doi.org/10.1002/ecs2.2543

[12] Liang, E., Wang, Y., Eckstein D., et al., 2011. Little change in the fir tree-line position on the southeastern Tibetan Plateau after 200 years of warming. New Phytologist. 190(3): 760-769. https://doi.org/10.1111/j.1469-8137.2010.03623.x

[13] Sabetizade, M., Gorji, M., Roudier, P., et al., 2021. Combination of MIR spectroscopy and 
environmental covariates to predict soil organic carbon in a semi-arid region. Catena. 196: 104844. https://doi:10.1016/j.catena.2020.104844

[14] Andriamananjara, A., Chevallier, T., Masse, D., et al., 2019. Land management modifies the temperature sensitivity of soil organic carbon, nitrogen and phosphorus dynamics in a Ferralsol. Applied Soil Ecology. 138: 112-122. https://doi.org/10.1016/j.apsoil.2019.02.023

[15] Zhang, Y., Li, C., Wang, M., 2019. Linkages of C: $\mathrm{N}$ : P stoichiometry between soil and leaf and their response to climatic factors along altitudinal gradients. Journal of Soils and Sediments. 19: 1820-1829. https://doi.org/10.1007/s11368-0182173-2

[16] Yu, M.F., Tao, Y., Liu, W., et al., 2020. C, N, and P stoichiometry and their interaction with different plant communities and soils in subtropical riparian wetlands. Environmental Science and Pollution Research. 27(3): https://doi.org/10.1007/s11356-019-07004-x

[17] Braak., C.J.F., Smilauer, P., 2002. Canoco reference manu'al and canodraw for windows user's guide: Software for canonical community ordination (version 4.5). www.canoco.com. Ithaca NY, USA.

[18] Liu, T., Wu, X., Li, H., et al., 2020. Soil organic matter, nitrogen and $\mathrm{pH}$ driven change in bacterial community following forest conversion. Forest Ecology and Management. 477: 118473. https://doi.org/10.1016/j.foreco.2020.118473

[19] Camenzind, T., Hättenschwiler, S., Treseder, K.K., et al., 2018. Nutrient limitation of soil microbial processes in tropical forests. Ecological Monographs. 88 (1): 4-21. https://doi.org/10.1002 lecm.1279

[20] Al-Rowaily, S.L., Al-Nomari, G., Assaeed, A.M., et al., 2020. Infection by Plicosepalus curviflorus mistletoe affects the nutritional elements of Acacia species and soil nutrient recycling in an arid rangeland. Plant Ecology. 221: 1017-1028. https://doi.org/10.1007/s11258-020-01058-5

[21] Dong, S.K., Sha, W., Su, X.K., et al. 2019. The impacts of geographic, soil and climatic factors on plant diversity, biomass and their relationships of the alpine dry ecosystems: cases from the Aerjin Mountain Nature Reserve, China. Ecological Engineering. 127: 170-177. https://doi.org/10.1016/j.ecoleng.2018.10.027

[22] D.K. Biswas., B.L. Ma., M.J. Morrison., 2019. Changes in leaf nitrogen and phosphorus content, photosynthesis, respiration, growth, and resource use efficiency of a rapeseed cultivar as affected by drought and high temperatures. Canadian Journal of Plant Science. 99(4): 413-419. https://doi.org/10.1139/cjps-2018-0023

[23] Leloup, J., Baude, M., Nunan, N., et al., 2018. Unravelling the effects of plant species diversity and aboveground litter input on soil bacterial communities. Geoderma. 317: 1-7. https://doi.org/10.1016/j.geoderma.2017.12.018

[24] Stéphane, Bazot., Zarafshar, M., 2020. Do tree plantations or cultivated fields have the same ability to maintain soil quality as natural forests? Applied Soil Ecology. 151: 1-10. https://doi.org/10.1016/j.apsoil.2020.103536

[25] Su, Y., Liu, J., Zhang, Y., et al., 2021. More drought leads to a greater significance of biocrusts to soil multifunctionality. Functional Ecology. 00: 1-12. https://doi:10.1111/1365-2435.13761

[26] Xu, S., Sardans, J., Zhang, J., et al., 2020. Variations in foliar carbon : nitrogen and nitrogen : phosphorus ratios under global change: a metaanalysis of experimental field studies. Scientific Reports. $\quad 10(1)$ : 12156. https://doi.org/10.1038/s41598-020-68487-0

[27] Fang, Y., Bhupinder, Pal., Singh, Damian., et al., 2020. Nutrient stoichiometry and labile carbon content of organic amendments control microbial biomass and carbon-use efficiency in a poorly structured sodic-subsoil. Biology and Fertility of Soils, $\quad \mathbf{5 6}(2)$ : 219-233. https://doi.org/10.1007/s00374-019-01413-3

[28] Yuan, X., Niu, D., Gherardi, L. A., et al., 2019. Linkages of stoichiometric imbalances to soil microbial respiration with increasing nitrogen addition: evidence from a long-term grassland experiment. Soil Biology and Biochemistry. 138: 107580 . https://doi.org/10.1016/j.soilbio.2019.107580

[29] Yue, K., Peng, Y., Fornara, D. A., et al., 2019. Responses of nitrogen concentrations and pools to multiple environmental change drivers: a metaanalysis across terrestrial ecosystems. Global Ecology and Biogeography. 28: 690-724. https://doi.org/10.1111/geb.12884

[30] Feng, J., Wei, K., Chen, Z., et al., 2019. Coupling and decoupling of soil carbon and nutrient cycles across an aridity gradient in the drylands of northern china: evidence from ecoenzymatic stoichiometry. Global Biogeochemical Cycles. 33(5): 559-569. https://doi.org/10.1029/2018GB006112

[31] Wang, Y., Ren, Z., Ma, P., et al., 2020. Effects of grassland degradation on ecological stoichiometry of soil ecosystems on the Qinghai-Tibet Plateau. Science of the Total Environment. 722: 137910. https://doi.org/10.1016/j.scitotenv.2020.137910

[32] N, Lei, Li, J., Chen, T., 2021. Respiration characteristics and its responses to hydrothermal seasonal changes in reconstructed soils. Scientific Reports, 11: 144. https://doi.org/10.1038/s41598020-80623-4

[33] Antisari, L.V., Papp R., Vianello G., et al., 2018. Effects of Douglas Fir stand age on soil chemical properties, nutrient dynamics, and enzyme activity: A case study in northern Apennines, Italy. Forests, 9: 641. https://doi.org/10.3390/f9100641 
[34] Delgado-Baquerizo, M., Eldridge, D.J., Maestre, F.T., et al., 2018. Aridity decouples C: N: P stoichiometry across multiple trophic levels in terrestrial ecosystems. Ecosystems. 21 (3): 459-468. https://doi:10.1007/s10021-017-0161-9

[35] Ai, Z., He, L., Xin, Q., Yang, T., et al., 2017. Slope aspect affects the non-structural carbohydrates and c: N: P stoichiometry of artemisia sacrorum on the Loess Plateau in China. Catena. 152: 9-17. https://doi.org/10.1016/j.catena.2016.12.024

[36] Tian, H., Chen, G., Zhang, C., et al., 2010. Pattern and variation of $\mathrm{C}$ : $\mathrm{N}$ : $\mathrm{P}$ ratios in China's soils: a synthesis of observational data. Biogeochemistry. 98(1-3): 139-151. https://doi.org/10.1007/s10533009-9382-0

[37] Zhang, J., Zhao, N., Liu, C., et al., 2018. C:N:P stoichiometry in China's forests: From organs to ecosystems. Ecology Letters. 32: 50-60. https://doi.org/10.1111/1365-2435.12979

[38] Xie, J., Chang, S., Zhang, Y., et al., 2016. Plant and soil ecological stoichiometry with vertical zonality on the northern slope of the middle tianshan mountains. Acta Ecologica Sinica. 36 (14): 43634372. (In Chinese) https://doi.org/10.5846/stxb201506301387

[39] Qin, H., Fu, X., Lu, Y., et al., 2019. Soil C: N: P stoichiometry at different altitudes in mao'er mountain, guangxi, china. Journal of Applied Ecology. 30(3): 711-717. (In Chinese) https://doi.org/10.13287/j.1001-9332.201903.027

[40] Yang, Y., Zhou, Y., Shi, Z., et al., 2020. Interactive elevation and land use on soil bacterial communities in the Tibetan Plateau. Pedosphere. 30(6): 817-831. https://doi.org/10.1016/S10020160(19)60836-2

[41] Feng, D., Bao, W., Pang, X., 2017. Consistent profile pattern and spatial variation of soil $\mathrm{C} / \mathrm{N} / \mathrm{P}$ stoichiometric ratios in the subalpine forests. Journal of Soils and Sediments. 17(8): 2054-2065. https://doi:10.1007/s11368-017-1665-9

[42] Devi, S.B., Sherpa S., 2019. Soil carbon and nitrogen stocks along the altitudinal gradient of the Darjeeling Himalayas, India. Environmental Monitoring and Assessment. 191(6): 361. https://doi.org/10.1007/s10661-019-7470-8

[43] Chen, X., Wang, G., Zhang, T., et al., 2017. Effects of warming and nitrogen fertilization on GHG flux in an alpine swamp meadow of a permafrost region. Science of the Total Environment. 601: 1389-1399. https://doi.org/10.1016/j.scitotenv.2017.06.028 